\title{
The Perception of MSU BTESL Practicum Students Towards the Idea of Using English Songs with Written Lyrics in Teaching Vocabulary
}

\author{
${ }^{1}$ Mohammad Ali Al-Saggaf, ${ }^{*}$, ${ }^{1}$ Norhafiza Azween Binti Sumali, 2 Mohammed \\ Mohammed Ali Abdulkhaleq
}

${ }^{1}$ School of Education and Social Sciences, Management and Science University, Shah Alam 40100, Malaysia

${ }^{2}$ Department of English Language \& Literature, Xiamen University Malaysia, Sepang 43900, Malaysia

\begin{tabular}{llll}
\hline Received: 13.03 .2021 & $\bullet$ & Accepted: 08.04.2021 & Published: 30.06.2021 \\
\hline
\end{tabular}

\begin{abstract}
Although English songs with written lyrics are already familiar in Malaysia, only a few recognize the potential use of the material in teaching vocabulary, especially among Malaysian English teachers. The researchers find it necessary to understand the perception towards the idea of using English songs with written lyrics in teaching vocabulary especially in the Malaysian context. This quantitative research aims to identify the MSU TESL practicum students' perception of using English songs with written lyrics in teaching vocabulary and find out if there is any difference according to gender and program (DTESL/BTESL) in the practicum students' perception. A total of 164 TESL practicum students are used as the sample in this research where an online questionnaire is distributed to collect data. The results reveal that the practicum students exhibit a positive perception towards the idea of using English songs with written lyrics in teaching vocabulary. No significant difference in perception is found regardless the gender and programs. The findings are hopefully to give significance to the English teachers and the English Language Teaching curriculum developers. Further recommendation is given for a better understanding of the perception.
\end{abstract}

Keywords: Teaching English as a Second Language, Second Language Teaching, Vocabulary Development, English Songs, Written Lyrics

\section{Introduction}

Like any other second language learners, many students in Malaysia are facing difficulties in mastering the English language which may include poor comprehension, lack of vocabulary, grammatical errors, and so on. Teaching the English language can be challenging for teachers, especially in teaching vocabulary knowledge to the students. Teachers play an essential role in making the teaching and learning process stimulating and fun simultaneously by using useful teaching aids. One of the teaching aids is English songs with written lyrics. Fortunately, English songs with written lyrics are reachable to everyone worldwide, which cover different contexts and genres that provide an opportunity for English language learners who face difficulties like lack of vocabulary to find a way to overcome them. This could potentially assist the students in language learning. Since the effectiveness of English songs with lyrics has been studied by many researchers,

* Corresponding Author: mas2002ye@gmail.com 
the researchers want to explore the perception of TESL Practicum students in MSU towards the idea of using English songs with written lyrics in teaching vocabulary and identify if there is any difference of perception towards the matter according to the gender and program (DTESL/BTESL).

\subsection{Problem Statement}

Almost all mediums on the Internet, such as YouTube and Spotify, come with the option of lyrics that accompanied the song. However, do teachers take good advantage of this matter? According to Xiowei (2010), "although preferred by college students, English songs seem unpopular among teachers." Zamin, Adzmi and Mohamad (2020) also mentioned that "the use of songs for second language teaching should be given attention as in the present era students are very close to songs." The researchers realize as far as to their knowledge, that there are not many researches have been done on the matter especially in the Malaysian context, that are using the TESL Practicum students as a sample population. In addition, not many researches have been done on this topic, at least in Malaysia, to truly understand the perception of MSU TESL practicum students towards the idea of using English songs with written lyrics in teaching vocabulary.

Hence, the researchers have a strong interest and feel the need to identify how the Malaysian TESL Practicum students who are going to teach students to perceive the idea of using English songs with written lyrics in teaching vocabulary especially based on different gender and program. Following are the research questions that will help in achieving the research objectives:

1. What is the perception of MSU TESL Practicum students towards the idea of using English songs with written lyrics in teaching vocabulary?

2. What is the difference, if any, according to gender in TESL Practicum students' perception towards the idea of using English songs with written lyrics in teaching vocabulary?

3. What is the difference, if any, according to program (DTESL/BTESL) in TESL Practicum students' perception towards the idea of using English songs with written lyrics in teaching vocabulary?

This current research will offer significance that is beneficial to the English language teachers and curriculum developer with no time boundaries. This research would allow teachers to acknowledge learners who have a high level of Musical Intelligence. They would be informed that these learners' learning styles should be emphasized as well. Thus, they need to include classroom activities that are based on English songs with written lyrics to motivate them to develop vocabulary.

Moreover, teachers would also be aware that English songs with written lyrics, with many repetitions,play an essential role in vocabulary recall and retention. Thus, they would be interested in using the method frequently for classroom activities. Furthermore, the teachers would also be informed on the importance of deciding songs that are of interest to learners, such as their preferences in the genre, context, and so on. Since the material is a type of audio-visual aid, students will have the motivation to learn as thematerial can be heard and seen. By inducing a high level of motivation and materials that they can see and listen to, students will be encouraged to learn English vocabulary better that will improve their vocabulary recall and retention.

Not only that, the English Language Teaching curriculum developers could be enlightened on the reasons why they should include English songs with written lyrics in the educational curriculum. It could be implemented as an exercise, task, or assignment where teachers could employ English songs with written lyrics to enhance learners' vocabulary development. This is since English songs with written lyrics can positively influence the comprehension of vocabulary practice in real context 
as it provides authentic settings for vocabulary expansions.

\section{Literature Review}

\subsection{Conceptual Framework}

Figure 2.1.1 displays the conceptual framework of this current research which is based on Krashen's Affective Filter Hypotheses (1984). The hypotheses stated that input, which is the English language, cannot be acquired by learners if there is a mental block such as anxiety or low self-esteem. Learning or acquiring the English language can be intimidating for some learners. Fortunately, English songs with written lyrics can be seen as a medium that can set a relaxed atmosphere, especially when it is used by learners to learn the English language. Thus, resulting in learners to be less anxious when they are trying to learn the language. Due to this, without the mental block, learners will be able to acquire the language, which in this research refers to the vocabulary, much easier. Learners will be more motivated to learn and receive input effectively.

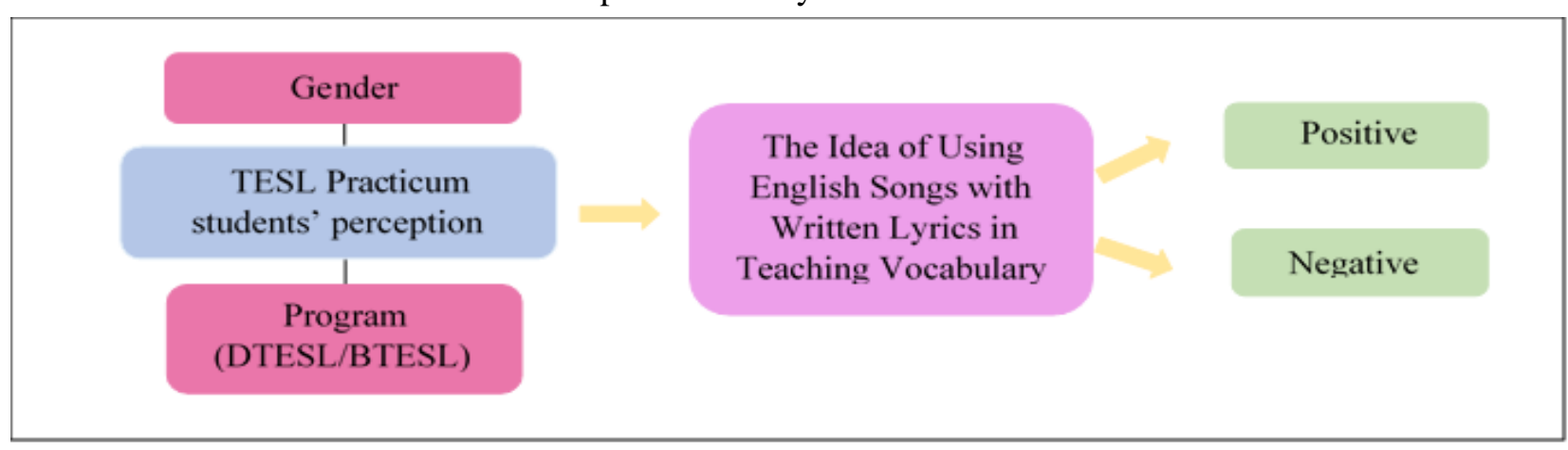

Figure 2.1.1 Conceptual Framework

\subsection{The use of English songs and lyrics in teaching and learning of vocabulary among teachers} and students

Nguyen and Nguyen (2020) conducted a study on teachers' perceptions on the use of songs in vocabulary instruction to language learners in Vietnam. The researchers realized that songs could provide a positive impact on vocabulary instruction. However, the problem stated is that there are not many researches in Vietnam that emphasized on teachers' perception towards employing English songs in vocabulary instruction to learners within the Vietnamese teaching context. From the analyzed data, the researchers disclosed that majority of the teachers agreed that songs are useful in teaching vocabulary to young learners. $98.7 \%$ identified songs as a tool in aiding learners' vocabulary retention, and $94.7 \%$ agreed that students were provided with opportunities to revise vocabulary through songs. Around two-thirds of the teachers firmly approved that learners could use songs to grasp and practice vocabulary, which is beneficial for their vocabulary expansion. Some of the teachers also played songs several to repeat the words. This showed how repetition is vital to help recognize and recall new lexical items. The researchers also claimed that songs are influential in vocabulary instruction in terms of the number of new words obtained, retention, enhancing attention, learning atmosphere, opportunities for learning and meaningful contexts.

Lestari and Hardiyanti (2020) conducted a research on exploring Indonesian EFL students' perspectives towards vocabulary learning autonomy through English songs. It is revealed that all of the students preferred slow beat music when learning vocabulary. The students acknowledged that it helped them to grasp the words quickly and listen to the pronunciation rather than in fast beat 
music. The students also came to an agreement that English songs provide authentic exposure to English words. This is because singers have different varieties of English, thus providing different words and dictions as how native speakers would speak.

Since songs come with different genres, the lyrics commonly follow suit to the particular genre and emotions that associate with it. Thus, students are likely to come across new words when they listen to different genres of English songs. Furthermore, they realized that the use of songs allowed them to feel the connection with the songs which help the students to learn the words better as the words were able to reflect their emotions. Lastly, all of the students firmly agreed that the songs were subconsciously allowing them to learn vocabulary. Through songs, they managed to retain the new vocabularies in long-term memory, unlike the intentional memorizing process that they usually had in class. From these findings, it is clear that students positively perceive English songs with lyrics as a mean to develop their vocabulary. This is due to the songs' ability to provide a much fun atmosphere and authentic words that could lead to the retention of vocabulary.

\subsection{Characteristics of the English songs with written lyrics for effective vocabulary teaching and learning}

Melody and rhythm.

Bahrami, Izadpanah and Bijani (2019) examined the impact of musical mnemonic on recalling and retaining of vocabulary. After analyzing the data gathered by Independent T-Test, the researchers found out that the experimental group obtained a higher mean score than the control group in both vocabulary recall and retention. The researchers noted that the experimental group could memorize more words than the control group. The findings indicated that musical mnemonics do have influence that could help students to learn and remember new vocabularies effectively.

\section{Comprehensible Song Lyrics}

Javadi-Safa (2018) investigated the impact of music among Persian English learners in the acquisition of English vocabulary. After the researcher has analyzed the independent t-test, he observed that the average mean score of vocabulary test from the experimental group was higher than the control group. The findings proved that songs helped learners in vocabulary learning, especially when the song lyrics are explicit and meet the students' proficiency level. When lyrics are matched with the proficiency level, students might be able to easily grasp the words and relate the newly learned words with their prior knowledge. The explicitness of the lyrics would more likely encourage students to remember and comprehend the meaning of the words better. As stated by the researcher, the findings could provide implications to English teachers.

\section{Genre}

Shakerian, Rezaei, Murnani and Moeinmanesh (2016) investigated the role of pop songs on vocabulary recall, attitude and retention among learners according to their gender. The researchers discovered that the musical group scored higher than the non-musical group. In terms of gender, it was revealed that both genders have no significant differences in performance and retention of vocabulary. Generally, the musical group significantly enhanced their vocabulary and showed positive attitudes when they were given songs in learning. It is known that pop songs are commonly created with rhythm and lyrics that are easily grasped. The pace of the songs usually is not too fast, which could be related to why students are more likely to choose the genre as their preference. 
Khairul and Azlina (2020) examined the use of action songs in improving vocabulary among pupils of the rural area. The researchers found out that the pupils positively acknowledge that they have improved their English vocabulary based on the results of the tests. Hence, from these results, we can see how songs can accelerate vocabulary knowledge if it is being practised repeatedly, which is beneficial in memorizing new words. Repetition in teaching and learning vocabulary is highly valued. This is due to the fact that the repeated occurrence of words which English songs with written lyrics could offer would encourage students to be more familiar with the words as they repeatedly come across with the words.

\section{Combination of Audio-Visual}

Dzanic and Pejic (2016) implemented a study on the effect of using songs on young learners and their motivation for learning English. Students were divided into Class A (Experimental group, EG) which songs were presented in a video format with lyrics during the lesson and Class B (Control Group, CG) which they only listened to the songs in audio formal with no visuals. The researchers revealed that for post-test, the Control Group displayed better vocabulary retention than the Experimental Group. Meanwhile, for the delayed post-test, the students in Control Group displayed greater results of recognizing and remembering the target words. From these findings, it could be seen that the use of audio and visual materials can assist in vocabulary retention and recall.

\subsection{Motivation through English songs with lyrics}

Malekian (2016) observed the relationship between English songs and vocabulary learning. The results found out that the number of words learned by Class A that used the songs was higher than Class B. Following to this, the research signified that soft-beat songs could assist students in learning new words and the usage of English songs could enhance motivation in students which indirectly improve their vocabulary learning. The music can be seen as a factor that enhances the learning environment, which boosts up students' enthusiasm when learning vocabulary. Thus, they tend to absorb more words which promote the recollection of the words from the song lyrics.

\subsection{Using English songs with lyrics in teaching vocabulary between different gender and the level of education}

Alipour, Gorjian and Zafari (2012) observed the effects of songs on EFL learners' vocabulary recall and retention according to a different gender. The researchers found out that there was indeed an effect of musical instruction that helped learners to recall vocabulary as the musical-mode group had a higher significant mean score. Furthermore, the researchers discovered that male gender performed better in recalling their vocabulary. Al-Azri, Al-Rashdi and Kazazi (2015) examined the implementation of songs as a support in vocabulary learning among young learners. It is revealed that there were slight differences of mean scores between genders. Females could recall the words more precisely than males with a percentage of $65 \%$ and had outperformed males in vocabulary retention generally.

Narayan (2020), who conducted an experimental study that investigated learners' vocabulary skills enhancement by means of English songs. It is revealed that the post-test mean score showed that the experimental group that had lesson using song with lyrics accompanied scored higher than the control group that had lesson without the song playing. The researcher noted that English songs assisted and encouraged the students in mastering vocabulary skills. The learners even favoured the usage of English songs as a pedagogical method to assist their vocabulary development.

Tomczak and Lew (2019) conducted a research on Teaching multi-word units with songs. Although the research is about multi-word units which are words that are glued together, it can also be seen as similar as learning new single words. Since the usage of songs is implemented in learning the words, 
the findings of this research are worth mentioning. The purpose of this research was to study on the effectiveness of teaching multi-word units through songs. After analyzing the results, the researchers revealed that for the immediate post-test, the Song group managed to recall more multi-words unit than the control group with a significant mean difference. Moreover, for the delayed post-test, it was discovered that the control group could recall less multi-words unit than the Song group a week after the teaching activity.

\subsection{Challenges of using English songs with lyrics in teaching vocabulary}

Kurnianto (2016) conducted a study on students' perception towards the use of song lyrics in learning English. From the interview, some challenges that the researcher had found were the vocabularies and grammar structure might be rigid for some students to comprehend. The accents of the singers could also influence the students' English learning.

\section{Methodology}

\subsection{Research Design}

For this current research, quantitative approach is used as it is helpful in gathering measurable data. The measurable data is referring to the number of responses which indicates an opinion or perception by the respondents on a particular statement which is related to the research topic. Therefore, the researchers decided to adapt a quantitative approach as it creates an explanation through objectivity revealed in the collected data. The researchers used a descriptive survey research design that emphasizes on the 'what' question of the research samples instead of the 'why'. The researcher wants to learn on the population's opinion or perception towards the problem or issue related to the current research topic.

\subsection{Sampling Methods}

The large population of the sample is from the TESL Practicum students of different programs (DTESL and BTESL) in Management and Science University, Shah Alam. Stratified Random sampling has been used to select the sample. The samples are divided into sub-groups following the stratified sampling technique(gender and program). The total of the large population is 286 students of TESL practicum students that are from different programs, Diploma in TESL (DTESL) and Bachelor in TESL (BTESL). After stratifying the population and the calculation is determined with the confidence level of $95 \%$, and the margin of error $5 \%$, the sample size is 164 students. For research question 2 , the researchers analyzed the data obtained from $70 \%$ of female samples and $30 \%$ of male samples. Meanwhile, for research question 3, the researchers analyzed the data from 34\% of DTESL program and $66 \%$ of BTESL program.

\subsection{Instrument}

The instrument that is used to collect data from the respondents is an online survey questionnaire which was a questionnaire adapted and modified from a research by Sevik (2011) on "Teacher views about using songs in teaching English to young learners." The questionnaire is divided into two main parts in which Part 1 consists of questions which ask on the respondents' demographic information such as gender and the program that they are currently taking. Meanwhile, Part 2 consists of 16 items regarding to the respondents' perceptions towards the idea of using English songs with written lyrics in teaching vocabulary and the questions are answered using Five-point Likert scale to indicate the respondents' answers. The scale ranged from Strongly Disagree (1), Disagree (2), Neutral (3), Agree (4), and Strongly Agree (5). 


\subsubsection{The Cronbach's Alpha test}

Since the survey questionnaire is adapted and modified, the researchers have done a pilot test in order to test the reliability and validity of the instrument. By providing the link to the online questionnaire through WhatsApp groups, the researchers managed to reach out to 30 respondents to complete the pilot test. Upon receiving 30 responses, the researchers analyzed the data obtained through the Statistical Package for the Social Sciences (SPSS) software. Following is the result of the pilot test, which the reliability statistics is measured with Cronbach's Alpha.

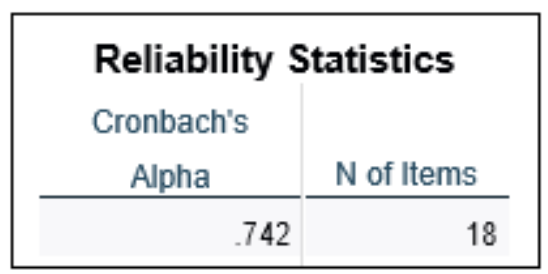

Figure 3.3.1.1 Cronbach's Alpha result

Figure 3.3.1.1 shows the reliability statistics of the instrument used for this current research. It describes that that the instrument is indeed reliable as the Cronbach's Alpha is 0.742 . This calculation indicated that the internal consistency of the questionnaire is acceptable.

\subsection{Data Collection Procedures}

In administering the online survey questionnaire, the researchers reaches out to the coordinators of the practicum students and asks help in spreading the link of the online questionnaire through their WhatsApp groups (DTESL and BTESL). The researchers have also managed to contact a few of the respondents directly by texting them personally through WhatsApp.

\subsection{Data Analysis Procedures}

As this research uses a quantitative approach, the numerical data obtained after analyzing the online questionnaire is analyzed using descriptive statistics. In order to analyze data, the researchers used statistics which is helpful in finding and describing the trends in the data. The researchers looked at the percentage, frequency and mean of every item. For the second and third research questions which focus on the gender and programs of the samples, the researchers ensure that the number of samples' data to be analyzed is matched with the percentage that represents the population. For gender, the researchers analyzed data from $86 \%$ of female samples and $14 \%$ of male samples. Meanwhile, for programs, the researchers analyzed data from $34 \%$ of DTESL program and $66 \%$ of BTESL. After running the data analysis, the researchers present the results in a table. The table is used to ensure the data could be explained easily and organized. It is also helpful to clearly present the patterns of findings.

\section{Results and Discussion}

\subsection{Demographic Information}

The researchers have analyzed 164 TESL practicum students from MSU Shah Alam. The students are from different programs, Diploma in TESL (DTESL) and Bachelor in TESL (BTESL). Through the SPSS software, the data frequency, percent and average mean were obtained. 


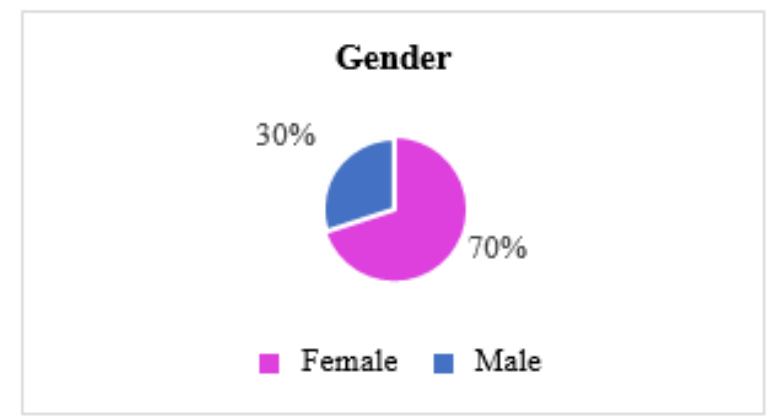

Figure 4.1.1 Percentage according to gender

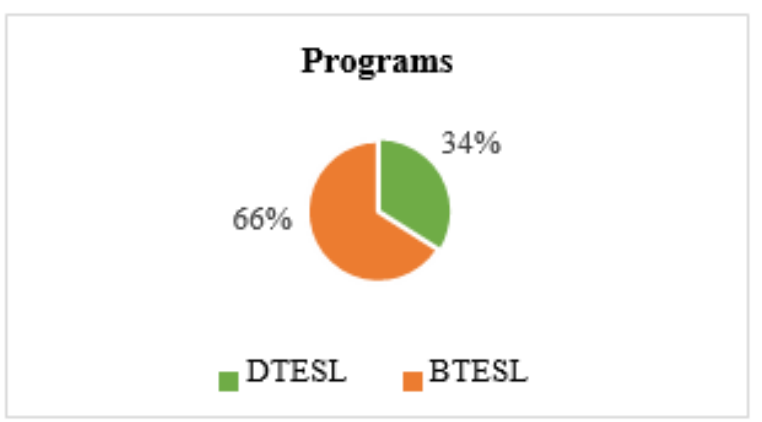

Figure 4.1.2 Percentage according to programs

Figure 4.1.1 and Figure 4.1.2 show that the respondents consist of female practicum students with the percentage of $70 \%$ and male practicum students with the percentage of $30 \% .34 \%$ of the practicum students are from DTESL program and $66 \%$ of them are from BTESL program.

\subsection{Research Question 1}

The data analysis is to answer the first research question; What is the perception of MSU TESL practicum students towards the idea of using English songs with written lyrics in teaching vocabulary? The data analysis is based on the responses obtained generally from the respondents of different genders and programs (DTESL/BTESL).

Average Mean

Table 4.2.1 Average mean for overall items

\begin{tabular}{|c|l|c|}
\hline NO. & \multicolumn{1}{|c|}{ ITEM } & MEAN \\
\hline 1. & $\begin{array}{l}\text { I believe that English songs with written lyrics should be included in English } \\
\text { language teaching curriculum. }\end{array}$ & 4.03 \\
\hline 2. & $\begin{array}{l}\text { I believe on the use of English songs with written lyrics as a means of teaching } \\
\text { vocabulary. }\end{array}$ & 4.12 \\
\hline 3. & $\begin{array}{l}\text { I believe that English songs with written lyrics are fun to use in teaching } \\
\text { vocabulary. }\end{array}$ & 2.29 \\
\hline 4. & I believe that English songs with written lyrics are full of pedagogical value. & 4.15 \\
\hline 5. & $\begin{array}{l}\text { I believe that I could easily access and find appropriate English songs with } \\
\text { written lyrics to use in teaching vocabulary. }\end{array}$ & 4.26 \\
\hline 6. & I am planning to use English songs with written lyrics in teaching vocabulary. & 4.29 \\
\hline 7. & $\begin{array}{l}\text { I believe that I will not use English songs with written lyrics in teaching } \\
\text { vocabulary. }\end{array}$ & 3.91 \\
\hline 8. & I believe that English songs with written lyrics could provide repetition such as & 4.16 \\
\hline
\end{tabular}




\begin{tabular}{|c|c|c|}
\hline & words or rhythms which results in vocabulary recall and retention. & \\
\hline 9. & $\begin{array}{l}\text { I believe that it is important to consider the type of songs when employing } \\
\text { English songs with written lyrics in teaching vocabulary (slow-beat songs/fast- } \\
\text { beat songs). }\end{array}$ & 3.99 \\
\hline 10. & $\begin{array}{l}\text { I believe that slow-beat English songs with written lyrics could help me in } \\
\text { teaching vocabulary to my students better. }\end{array}$ & 4.15 \\
\hline 11. & $\begin{array}{l}\text { I believe that fast-beat English songs with written lyrics could help me in } \\
\text { teaching vocabulary to my students better. }\end{array}$ & 3.96 \\
\hline 12. & $\begin{array}{l}\text { I believe that the combination of audio-visual in English songs with written } \\
\text { lyrics would be helpful in vocabulary recall and retention. }\end{array}$ & 3.40 \\
\hline 13. & $\begin{array}{l}\text { I believe that using English songs with written lyrics to teach vocabulary could } \\
\text { distract my students' attention during the lesson. }\end{array}$ & 4.24 \\
\hline 14. & $\begin{array}{l}\text { I believe that using English songs with written lyrics would reduce my students' } \\
\text { anxiety when learning new vocabulary. }\end{array}$ & 3.03 \\
\hline 15. & $\begin{array}{l}\text { I believe that using English songs with written lyrics would not be effective in } \\
\text { teaching vocabulary to my students. }\end{array}$ & 2.59 \\
\hline 16. & $\begin{array}{l}\text { I believe that using English songs with written lyrics would help my students to } \\
\text { learn vocabulary faster. }\end{array}$ & 4.13 \\
\hline & AVERAGE MEAN & 3.79 \\
\hline
\end{tabular}

Figure 4.2.1 Mean of each item for Research Question 1

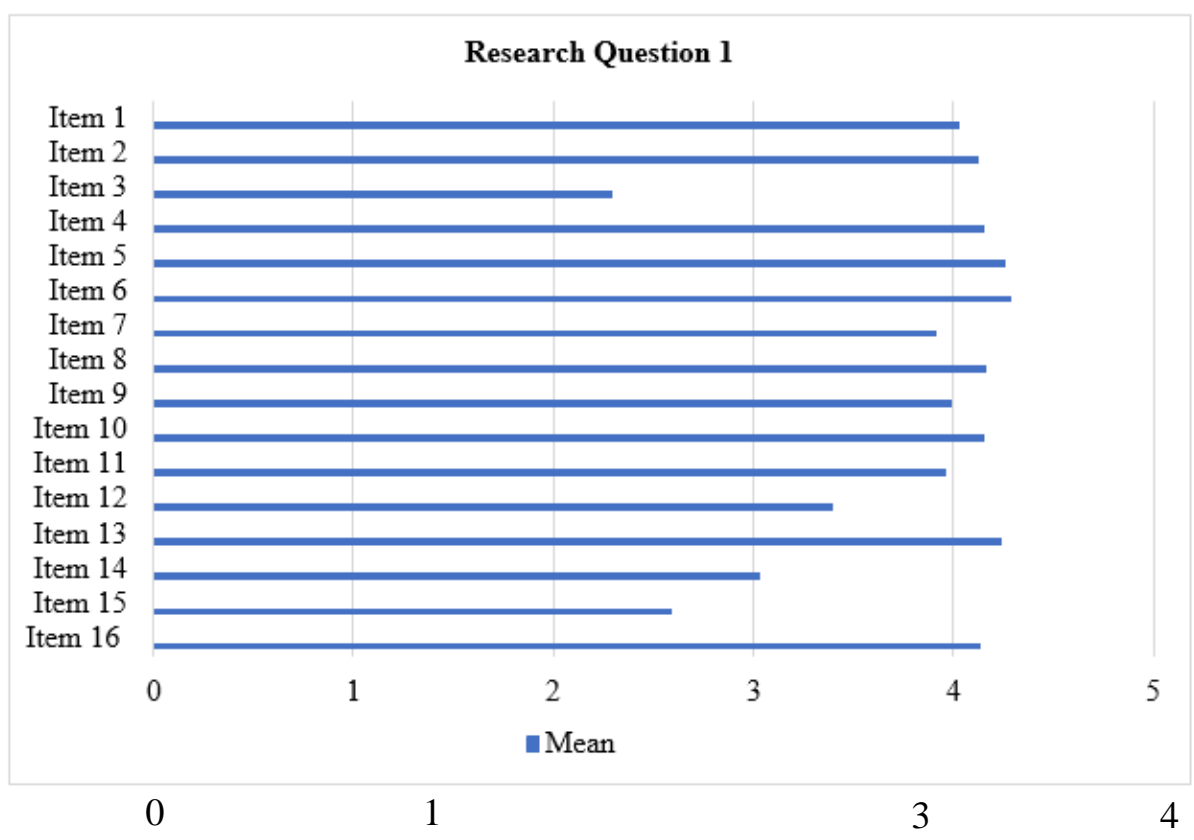

Figure 4.2.1 Mean of each item for Research Question 1

Table 4.2.1 shows the average mean of all items and Figure 4.2.1 shows the mean of each item for the analysis of research question 1 . The average mean obtained is 3.79 which shows that the practicum students show positive perception towards the idea of using English songs with written lyrics in teaching vocabulary.

\subsection{Research Question 2}

The data analysis is to answer the second research question; What is the difference, if any, according to gender in TESL Practicum students' perception towards the idea of using English songs with 
10 Al-Saggaf, et.al.: The Perception of MSU BTESL Practicum Students Towards the Idea of Using English Songs with Written Lyrics in Teaching Vocabulary

written lyrics in teaching vocabulary? The results are obtained by analyzing data obtained from $70 \%$ of female practicum students and $30 \%$ of male practicum students.

Average Mean (Female Practicum Students)

Table 4.3.1 Average mean for overall items (Female Practicum Students)

\begin{tabular}{|c|l|c|}
\hline NO. & \multicolumn{1}{|c|}{ ITEM } & MEAN \\
\hline 1. & $\begin{array}{l}\text { I believe that English songs with written lyrics should be included in English } \\
\text { language teaching curriculum. }\end{array}$ & 3.97 \\
\hline 2. & $\begin{array}{l}\text { I believe in the use of English songs with written lyrics as a means of teaching } \\
\text { vocabulary. }\end{array}$ & 4.09 \\
\hline 3. & $\begin{array}{l}\text { I believe that English songs with written lyrics are fun to use in teaching } \\
\text { vocabulary. }\end{array}$ & 2.23 \\
\hline 4. & I believe that English songs with written lyrics are full of pedagogical value. & 4.10 \\
\hline 5. & $\begin{array}{l}\text { I believe that I could easily access and find appropriate English songs with } \\
\text { written lyrics to use in teaching vocabulary. }\end{array}$ & 4.30 \\
\hline 6. & I am planning to use English songs with written lyrics in teaching vocabulary. & 4.29 \\
\hline 7. & $\begin{array}{l}\text { I believe that I will not use English songs with written lyrics in teaching } \\
\text { vocabulary. }\end{array}$ & 3.83 \\
\hline 8. & $\begin{array}{l}\text { I believe that English songs with written lyrics could provide repetition such as } \\
\text { words or rhythms which results in vocabulary recall and retention. }\end{array}$ & 4.10 \\
\hline 9. & $\begin{array}{l}\text { I believe that it is important to consider the type of songs when employing } \\
\text { English songs with written lyrics in teaching vocabulary (slow-beat songs/fast- } \\
\text { beat songs). }\end{array}$ & 3.91 \\
\hline 10. & $\begin{array}{l}\text { I believe that slow-beat English songs with written lyrics could help me in } \\
\text { teaching vocabulary to my students better. }\end{array}$ & 3.15 \\
\hline 11. & $\begin{array}{l}\text { I believe that fast-beat English songs with written lyrics could help me in } \\
\text { teaching vocabulary to my students better. }\end{array}$ & 3.90 \\
\hline 12. & $\begin{array}{l}\text { I believe that the combination of audio-visual in English songs with written } \\
\text { lyrics would be helpful in vocabulary recall and retention. }\end{array}$ & 3.41 \\
\hline 13. & $\begin{array}{l}\text { I believe that using English songs with written lyrics to teach vocabulary could } \\
\text { distract my students' attention during the lesson. }\end{array}$ & 4.19 \\
\hline 14. & $\begin{array}{l}\text { I believe that using English songs with written lyrics would reduce my students' } \\
\text { anxiety when learning new vocabulary. }\end{array}$ & $\begin{array}{l}\text { I believe that using English songs with written lyrics would not be effective in } \\
\text { teaching vocabulary to my students. }\end{array}$ \\
\hline 16. & $\begin{array}{l}\text { I believe that using English songs with written lyrics would help my students to } \\
\text { learn vocabulary faster. }\end{array}$ & 4.11 \\
\hline & \multicolumn{1}{|c|}{ AVERAGE MEAN } \\
\hline 15.77 \\
\hline
\end{tabular}

Average Mean (Male Practicum Students)

Table 4.3.2 Average mean for overall items (Male Practicum Students)

\begin{tabular}{|c|l|c|}
\hline NO. & \multicolumn{1}{|c|}{ ITEM } & MEAN \\
\hline 1. & $\begin{array}{l}|c| \\
\text { I believe that English songs with written lyrics should be included in English } \\
\text { language teaching curriculum. }\end{array}$ & 4.16 \\
\hline 2. & I believe on the use of English songs with written lyrics as a means of teaching & 4.18 \\
\hline
\end{tabular}




\begin{tabular}{|c|l|c|}
\hline & vocabulary. & \\
\hline 3. & $\begin{array}{l}\text { I believe that English songs with written lyrics are fun to use in teaching } \\
\text { vocabulary. }\end{array}$ & 2.43 \\
\hline 4. & I believe that English songs with written lyrics are full of pedagogical value. & 4.24 \\
\hline 5. & $\begin{array}{l}\text { I believe that I could easily access and find appropriate English songs with } \\
\text { written lyrics to use in teaching vocabulary. }\end{array}$ & 4.14 \\
\hline 6. & I am planning to use English songs with written lyrics in teaching vocabulary. & 4.31 \\
\hline 7. & $\begin{array}{l}\text { I believe that I will not use English songs with written lyrics in teaching } \\
\text { vocabulary. }\end{array}$ & 4.08 \\
\hline 8. & $\begin{array}{l}\text { I believe that English songs with written lyrics could provide repetition such as } \\
\text { words or rhythms which results in vocabulary recall and retention. }\end{array}$ & 4.31 \\
\hline 9. & $\begin{array}{l}\text { I believe that it is important to consider the type of songs when employing } \\
\text { English songs with written lyrics in teaching vocabulary (slow-beat songs/fast- } \\
\text { beat songs). }\end{array}$ & 4.16 \\
\hline 10. & $\begin{array}{l}\text { I believe that slow-beat English songs with written lyrics could help me in } \\
\text { teaching vocabulary to my students better. }\end{array}$ & 4.16 \\
\hline 11. & $\begin{array}{l}\text { I believe that fast-beat English songs with written lyrics could help me in } \\
\text { teaching vocabulary to my students better. }\end{array}$ & 4.12 \\
\hline 12. & $\begin{array}{l}\text { I believe that the combination of audio-visual in English songs with written } \\
\text { lyrics would be helpful in vocabulary recall and retention. }\end{array}$ & 3.37 \\
\hline 13. & $\begin{array}{l}\text { I believe that using English songs with written lyrics to teach vocabulary could } \\
\text { distract my students' attention during the lesson. }\end{array}$ & 4.37 \\
\hline 14. & $\begin{array}{l}\text { I believe that using English songs with written lyrics would reduce my students' } \\
\text { anxiety when learning new vocabulary. }\end{array}$ & 2.67 \\
\hline 15. & $\begin{array}{l}\text { I believe that using English songs with written lyrics would not be effective in } \\
\text { teaching vocabulary to my students. }\end{array}$ & $\begin{array}{l}\text { I believe that using English songs with written lyrics would help my students to } \\
\text { learn vocabulary faster. }\end{array}$ \\
\hline & \multicolumn{1}{|c|}{ AVRAGE MEAN } \\
\hline 16.16 \\
\hline
\end{tabular}

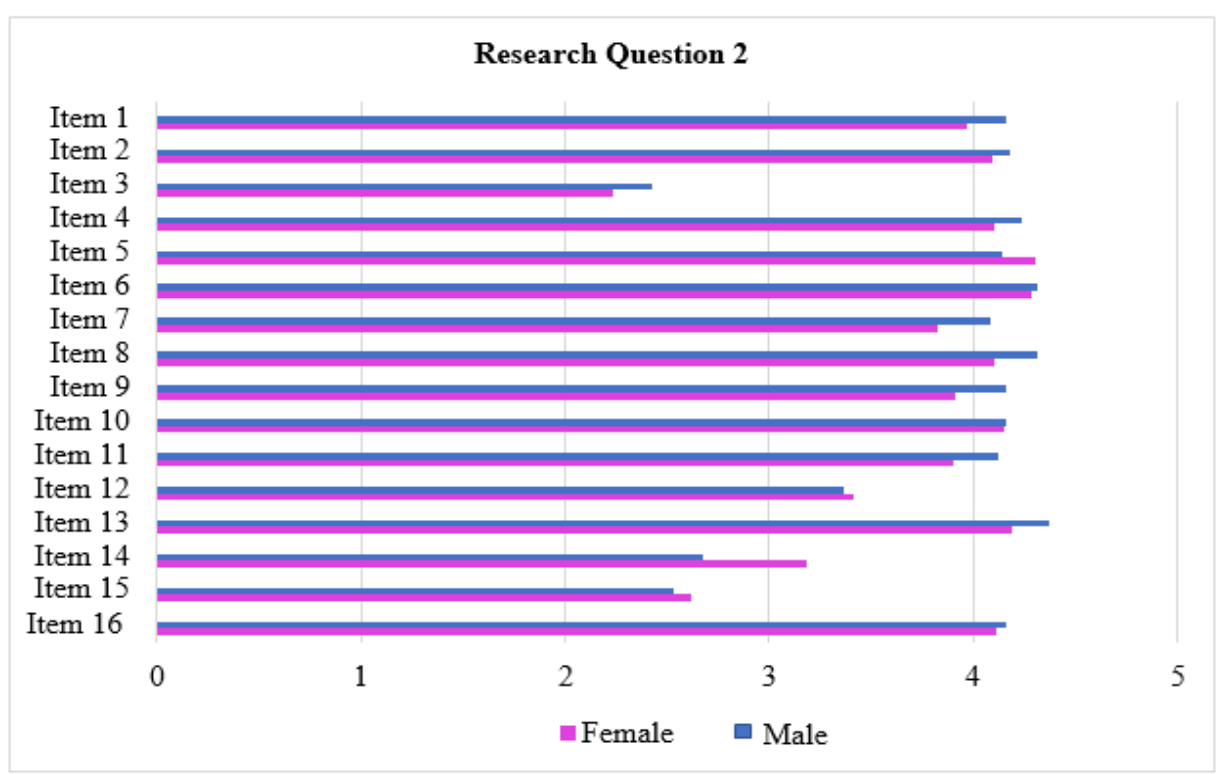

Figure 4.3.1 Mean of each item for Research Question 2 
12 Al-Saggaf, et.al.: The Perception of MSU BTESL Practicum Students Towards the Idea of Using English Songs with Written Lyrics in Teaching Vocabulary

Table 4.3.1 and Table 4.3.2 show the average mean of all items, and Figure 4.3.1 shows the mean of each item for research question 2. As stated in Table 4.3.1, it can be seen that the average mean for the female TESL practicum students is 3.77. Meanwhile, according to Table 4.3.2, the average mean for the male TESL practicum students is 3.84 .

\subsection{Research Question 3}

The data analysis is to answer the third research question; what is the difference, if any, according to program (DTESL/BTESL) in TESL Practicum students' perception towards the idea of using English songs with written lyrics in teaching vocabulary. The results are obtained by analyzing data obtained from $34 \%$ of DTESL practicum students and $66 \%$ of BTESL practicum students.

Average Mean (DTESL Practicum Students)

Table 4.4.1 Average mean for overall items (DTESL Practicum Students)

\begin{tabular}{|c|l|c|}
\hline NO. & \multicolumn{1}{|c|}{ ITEM } & MEAN \\
\hline 1. & $\begin{array}{l}\text { I believe that English songs with written lyrics should be included in English } \\
\text { language teaching curriculum. }\end{array}$ & 4.29 \\
\hline 2. & $\begin{array}{l}\text { I believe on the use of English songs with written lyrics as a means of teaching } \\
\text { vocabulary. }\end{array}$ & 4.18 \\
\hline 3. & $\begin{array}{l}\text { I believe that English songs with written lyrics are fun to use in teaching } \\
\text { vocabulary. }\end{array}$ & 2.43 \\
\hline 4. & I believe that English songs with written lyrics are full of pedagogical value. & 4.25 \\
\hline 5. & $\begin{array}{l}\text { I believe that I could easily access and find appropriate English songs with } \\
\text { written lyrics to use in teaching vocabulary. }\end{array}$ & 4.13 \\
\hline 6. & I am planning to use English songs with written lyrics in teaching vocabulary. \\
\hline 7. & $\begin{array}{l}\text { I believe that I will not use English songs with written lyrics in teaching } \\
\text { vocabulary. }\end{array}$ & 4.45 \\
\hline 8. & $\begin{array}{l}\text { I believe that English songs with written lyrics could provide repetition such as } \\
\text { words or rhythms which results in vocabulary recall and retention. }\end{array}$ & 3.95 \\
\hline 9. & $\begin{array}{l}\text { I believe that it is important to consider the type of songs when employing } \\
\text { English songs with written lyrics in teaching vocabulary (slow-beat songs/fast- } \\
\text { beat songs). }\end{array}$ & 4.34 \\
\hline 10. & $\begin{array}{l}\text { I believe that slow-beat English songs with written lyrics could help me in } \\
\text { teaching vocabulary to my students better. }\end{array}$ & 4.30 \\
\hline 11. & $\begin{array}{l}\text { I believe that fast-beat English songs with written lyrics could help me in } \\
\text { teaching vocabulary to my students better. }\end{array}$ & 4.29 \\
\hline 12. & $\begin{array}{l}\text { I believe that the combination of audio-visual in English songs with written } \\
\text { lyrics would be helpful in vocabulary recall and retention. }\end{array}$ & 3.45 \\
\hline 13. & $\begin{array}{l}\text { I believe that using English songs with written lyrics to teach vocabulary could } \\
\text { distract my students' attention during the lesson. }\end{array}$ & 4.30 \\
\hline 14. & $\begin{array}{l}\text { I believe that using English songs with written lyrics would reduce my students' } \\
\text { anxiety when learning new vocabulary. }\end{array}$ & 2.77 \\
\hline 15. & $\begin{array}{l}\text { I believe that using English songs with written lyrics would not be effective in } \\
\text { teaching vocabulary to my students. }\end{array}$ & $\begin{array}{l}\text { I believe that using English songs with written lyrics would help my students to } \\
\text { learn vocabulary faster. }\end{array}$ \\
\hline & \multicolumn{1}{|c|}{ AVEAGE MEAN } \\
\hline
\end{tabular}


Average Mean (BTESL Practicum Students)

Table 4.4.2 Average mean for overall items (BTESL Practicum Students)

\begin{tabular}{|c|l|c|}
\hline NO. & \multicolumn{1}{|c|}{ ITEM } & MEAN \\
\hline 1. & $\begin{array}{l}\text { I believe that English songs with written lyrics should be included in English } \\
\text { language teaching curriculum. }\end{array}$ & 3.90 \\
\hline 2. & $\begin{array}{l}\text { I believe on the use of English songs with written lyrics as a means of teaching } \\
\text { vocabulary. }\end{array}$ & 4.08 \\
\hline 3. & $\begin{array}{l}\text { I believe that English songs with written lyrics are fun to use in teaching } \\
\text { vocabulary. }\end{array}$ & 2.22 \\
\hline 4. & I believe that English songs with written lyrics are full of pedagogical value. & 4.09 \\
\hline 5. & $\begin{array}{l}\text { I believe that I could easily access and find appropriate English songs with } \\
\text { written lyrics to use in teaching vocabulary. }\end{array}$ & 4.32 \\
\hline 6. & I am planning to use English songs with written lyrics in teaching vocabulary. \\
\hline 7. & $\begin{array}{l}\text { I believe that I will not use English songs with written lyrics in teaching } \\
\text { vocabulary. }\end{array}$ & 4.21 \\
\hline 8. & $\begin{array}{l}\text { I believe that English songs with written lyrics could provide repetition such as } \\
\text { words or rhythms which results in vocabulary recall and retention. }\end{array}$ & 3.89 \\
\hline 9. & $\begin{array}{l}\text { I believe that it is important to consider the type of songs when employing } \\
\text { English songs with written lyrics in teaching vocabulary (slow-beat songs/fast- } \\
\text { beat songs). }\end{array}$ & 3.07 \\
\hline 10. & $\begin{array}{l}\text { I believe that slow-beat English songs with written lyrics could help me in } \\
\text { teaching vocabulary to my students better. }\end{array}$ & 4.07 \\
\hline 11. & $\begin{array}{l}\text { I believe that fast-beat English songs with written lyrics could help me in } \\
\text { teaching vocabulary to my students better. }\end{array}$ & 3.80 \\
\hline 12. & $\begin{array}{l}\text { I believe that the combination of audio-visual in English songs with written } \\
\text { lyrics would be helpful in vocabulary recall and retention. }\end{array}$ & 3.37 \\
\hline 13. & $\begin{array}{l}\text { I believe that using English songs with written lyrics to teach vocabulary could } \\
\text { distract my students' attention during the lesson. }\end{array}$ & 4.21 \\
\hline 14. & $\begin{array}{l}\text { I believe that using English songs with written lyrics would reduce my students' } \\
\text { anxiety when learning new vocabulary. }\end{array}$ & $\begin{array}{l}\text { AVERAGE MEAN } \\
\text { teaching vocabulary to my students. }\end{array}$ \\
\hline 15. & $\begin{array}{l}\text { I believe that using English songs with written lyrics would help my students to } \\
\text { learn vocabulary faster. }\end{array}$ & 4.06 \\
\hline & \multicolumn{1}{|c|}{ A } \\
\hline
\end{tabular}




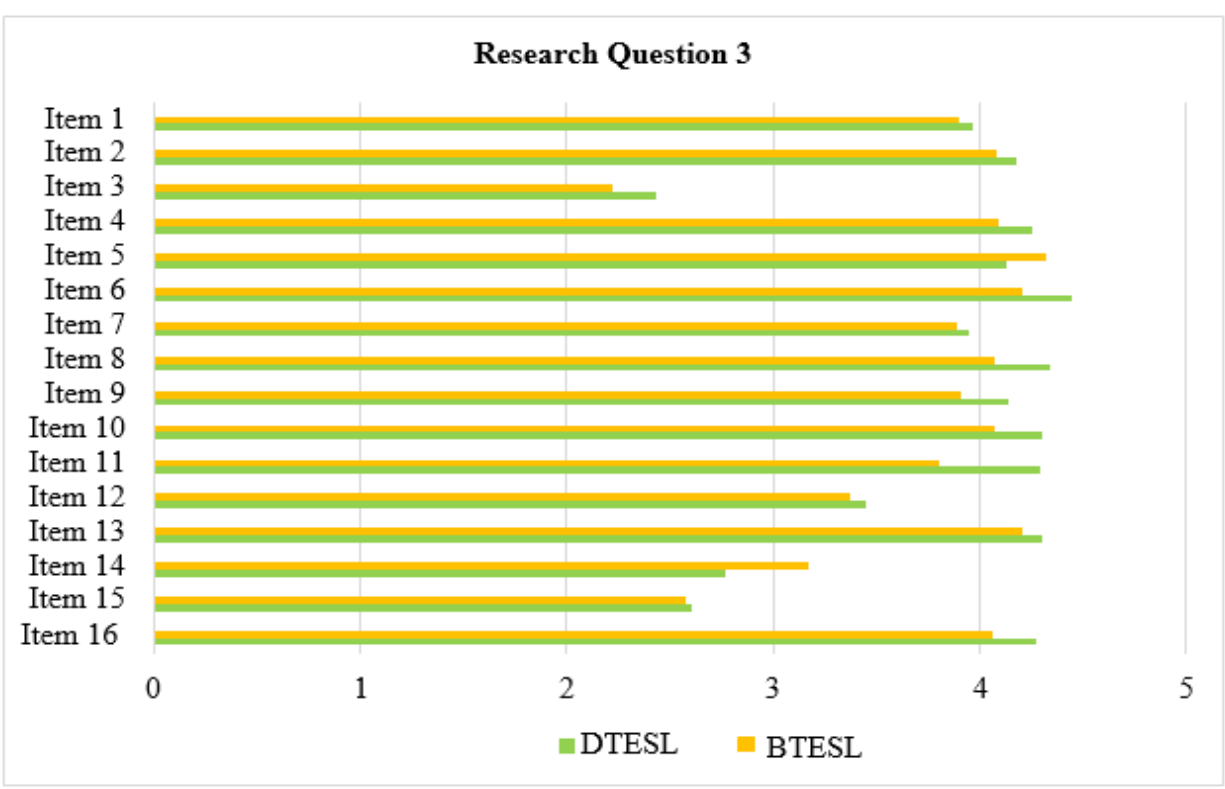

Figure 4.4.1 Mean of each item for Research Question 3

Table 4.4.1 and Table 4.4.2 show the average mean for overall items and Figure 4.4.1 shows the mean of each item for research question 3. As stated in Table 4.4.1, it can be seen that the average mean for the DTESL practicum students is 3.88. Meanwhile, according to Table 4.4.2, the average mean for the BTESL practicum students is 3.75 .

For research question one, the results discover that majority of the TESL practicum students perceive positively towards including the use of English songs with written lyrics in the English language curriculum as a means of teaching vocabulary. It can be seen as the students believe that English songs with written lyrics should be included in English language teaching curriculum as well as they believe on the use of English songs with written lyrics as a means of teaching vocabulary. Most of the practicum students lean on positively towards the idea of using English songs with written lyrics in teaching vocabulary. This can be portrayed as they agree to the extent of strongly agree that English songs with written lyrics are fun to use in teaching vocabulary and are full of pedagogical value. Furthermore, most of the practicum students believe that they could easily access and find appropriate English songs with written lyrics to use in teaching vocabulary. This can be indicated that with today's technology, the presence of numerous platforms such as YouTube and Spotify can make English songs with written lyrics to be easily found and streamed online. They also have stated firmly that they plan on using English songs with written lyrics in teaching vocabulary. It is most likely to say that they could see what the materials can do for students in learning vocabulary and for them as teachers in teaching vocabulary. Not only that, they strongly believe that English songs with written lyrics could provide repetition such as words or rhythms which results in vocabulary recall and retention. According to a research by Tse (2015), when the teachers played songs several times to repeat the words, it helped students to recognize and recalling new lexical items. This shows that the repetition element in songs with lyrics is useful in teaching vocabulary as students can retain vocabulary effectively. Positively, they believe in the importance of considering the type of songs when employing English songs with written lyrics in teaching vocabulary (slow-beat songs/fast-beat songs). The practicum students believe that slow-beat English songs with written lyrics could help them in teaching vocabulary to their students better. This is aligned to a research by Lestari and Hardiyanti (2020) which revealed that students preferred slow beat music when learning vocabulary. The students 
acknowledged that it helped them to grasp the words quickly and listen to the pronunciation rather than in fast beat music. Moreover, the practicum students believe that the combination of audiovisual in English songs with written lyrics would be helpful in vocabulary recall and retention. The majority of the practicum students disagree that using English songs with written lyrics to teach vocabulary could distract their students' attention during the lesson. This means that they believe English songs with written lyrics are not likely to distract their students' attention during the lesson. It is also has been proven that most of the practicum students are leaning on the positive perception as they firmly agree to the extent of strongly agree that using English songs with written lyrics would reduce their students' anxiety when learning new vocabulary. This finding can be related according to a research by Phisutthangkoon and Panich (2016), which they discovered that students found it relaxing when learning vocabulary through song-based activities. This can be connected to the Krashen's Affective Filter Hypotheses that states when mental block such as anxiety is lessened, the learners of a second language can effectively receive the input. Thus, by decreasing students' anxiety and increasing their motivation to learn better when teachers apply English songs with written lyrics in teaching vocabulary. Following to that, majority of the practicum students disagree that using English songs with written lyrics would not be effective in teaching vocabulary to their students. This means that they believe that using English songs with written lyrics indeed would be effective in teaching vocabulary to their students. They also view that using English songs with written lyrics would help their students to learn vocabulary faster. As noted in a research by Narayan (2020), English songs assisted and encouraged students in mastering vocabulary skills. Based on the data analysis, in answering research question 1, with the average mean of overall items is 3.79 , it is proven that MSU TESL practicum students show a positive response towards the idea of using English songs with written lyrics in teaching vocabulary.

For research question 2, the average mean of female responses for overall 16 items is 3.77. Meanwhile, from male responses is 3.84. This indicates that both female and male practicum students are leaning towards showing a positive perception towards the idea of using English songs with written lyrics in teaching vocabulary. Majority of the female and male practicum students believe that English songs with written lyrics should be included in English language teaching curriculum and they believe on the use of English songs with written lyrics as a means of teaching vocabulary. Most of the female and male practicum students believe that English songs with written lyrics are fun to use in teaching vocabulary and are full of pedagogical values. They also believe that they could easily access and find appropriate English songs with written lyrics to use in teaching vocabulary and plan to use the materials in teaching vocabulary. Furthermore, they believe that English songs with written lyrics could provide repetition such as words or rhythms, which results in vocabulary recall and retention. The female and male practicum students firmly believe that it is important to consider the type of songs when employing English songs with written lyrics in teaching vocabulary (slow-beat songs/fast-beat songs). This shows that they acknowledge how the type of songs could give effect in teaching vocabulary and for students to learn effectively. Majority of them also believe that slow-beat English songs with written lyrics could help them in teaching vocabulary to their students better. They declared that they believe the combination of audio-visual in English songs with written lyrics would be helpful in vocabulary recall and retention. There is a slight difference of opinion where the female practicum students believe that using English songs with written lyrics to teach vocabulary is less likely to distract their students' attention during the lesson. Meanwhile, for male practicum students, they disagree with the statement. Besides that, the majority of the female and male practicum students believe that using English songs with written lyrics would reduce 
their students' anxiety when learning new vocabulary. Lastly, they also believe that using English songs with written lyrics would indeed be effective in teaching vocabulary to their students and would help their students to learn vocabulary faster. Since the average mean of overall items for both female and male practicum students show that they have a positive perception, thus, to answer research question 2, there is no significant difference in perception towards the idea of using English songs with written lyrics in teaching vocabulary despite the gender among the MSU TESL practicum students. This is aligned to a previous research by Shakerian, Rezaei, Murnani and Moeinmanesh (2016) which revealed that both female and male genders have no significant differences in performance and retention of vocabulary. However, the result, particularly for research question 2, is opposed by Alipour, Gorjian and Zafari (2012) which discovered in their research that there were slight differences between gender as they found out male gender performed better in recalling their vocabulary than the female gender.

For research question 3, the average mean for overall 16 items according to the responses by DTESL practicum students is 3.88. Meanwhile, according to the responses by BTESL practicum students is 3.75. Both practicum students from DTESL and BTESL programs are show a positive perception towards the idea of using English songs with written lyrics in teaching vocabulary. Majority of the practicum students from both programs believe that English songs with written lyrics should be included in English language teaching curriculum and they believe on the use of English songs with written lyrics as a means of teaching vocabulary. Most of the DTESL and BTESL practicum students believe that English songs with written lyrics are fun to use in teaching vocabulary and are full of pedagogical values. They also believe that they could easily access and find appropriate English songs with written lyrics to use in teaching vocabulary and plan to use the materials in teaching vocabulary. Next, they believe that English songs with written lyrics could provide repetition such as words or rhythms, which results in vocabulary recall and retention. The DTESL and BTESL practicum students decisively believe that it is important to consider the type of songs when employing English songs with written lyrics in teaching vocabulary (slow-beat songs/fast-beat songs). Majority of them also believe that either slow-beat or fast-beat English songs with written lyrics could help them in teaching vocabulary to their students better. They declared that they believe the combination of audio-visual in English songs with written lyrics would be helpful in vocabulary recall and retention. Furthermore, both of the DTESL and BTESL practicum students believe that using English songs with written lyrics to teach vocabulary is less likely to distract their students' attention during the lesson. Besides that, the majority of the female and male practicum students believe that using English songs with written lyrics would reduce their students' anxiety when learning new vocabulary. Lastly, they also believe that using English songs with written lyrics would indeed be effective in teaching vocabulary to their students and would help their students to learn vocabulary faster. Since the average mean of overall items for both DTESL and BTESL practicum students show that they have a positive perception, thus, in answering research question 3, there is no significant difference in perception towards the idea of using English songs with written lyrics in teaching vocabulary despite the different programs among the MSU TESL practicum students. 


\section{Conclusion}

In conclusion, this current research has successfully answered all of the research questions. The findings prove that the MSU TESL practicum students show a positive perception towards the idea of using English songs with written lyrics in teaching vocabulary despite the differences in gender and programs (DTESL/BTESL). From the findings revealed through this research, it is hoped to provide insights to future or current English teachers and the English Language Teaching curriculum developers regarding the idea of using English songs with written lyrics in teaching vocabulary. For future researchers who are doing research of a similar topic, it would be helpful to use the findings as reference. For better results, conducting an interview with the sample of population studied could be beneficial in developing a well understanding of their perception towards the idea of using English songs with written lyrics in teaching vocabulary.

\section{References}

[1] Alipour, M., Gorjian, B. y Zafari, I. (2012). The effects of songs on EFL learners' vocabulary recall and retention: The case of gender. Advances in Digital Multimedia (ADMM), 1(3), 140- 143. http://citeseerx.ist.psu.edu/viewdoc/download?doi=10.1.1.871.7094\&rep=rep1\&type=pdf

[2] Al-Azri, Rashid., Al-Rashdi, Majid Hilal. \& Kazazi, Lavdim. (2015) Using Songs to Support Vocabulary Learning for Grade Four Pupils. INTERNATIONAL JOURNAL OF SCIENTIFIC \& TECHNOLOGY RESEARCH VOLUME 4, ISSUE 06, 40-45. http://www.ijstr.org/final- print/june2015/Using-Songs-ToSupport-Vocabulary-LearningFor-Grade-Four-Pupils.pdf

[3] Bahrami, Zahra \& Izadpanah, Siros \& Bijani, Houman. (2019). The Impact of Musical Mnemonic on Vocabulary Recalling of Iranian Young Learners. International Journal of Instruction. http://dx.doi.org/10.29333/iji.2019.12163a

[4] Delibegovic Dzanic, Nihada \& Pejic, Alisa. (2016). The Effect of Using Songs on Young Learners and Their Motivation for Learning English. NETSOL: New Trends in Social and Liberal Sciences. 1. 40-54. http://dx.doi.org/10.24819/netsol2016.8

[5] Du, X. (2010). The Affective Filter in Second Language Teaching. Asian Social Science. 5(8), 162-165. https://doi.org/10.5539/ass.v5n8p162

[6] Fu, Xiaowei (2010). Strategies of Learning English Vocabulary from Pop Songs: A Study among College Students in China. Specific Languages Social Sciences, 1-51. urn:nbn:se:hkr:diva-6764

[7] Khairul, Nurnadirah \& Abdul Aziz, Azlina. (2020). The Use of Action Songs in Developing Vocabulary among pupils of the rural area. International Journal of Scientific and Research Publications (IJSRP). http://dx.doi.org/10.29322/IJSRP.10.02.2020.p9808

[8] Kurnianto, Sidik. (2016) STUDENTS' PERCEPTION TOWARDS THE USE OF SONG LYRICS IN LEARNING ENGLISH AT ENGLISH EDUCATION DEPARTMENT OF UNIVERSITAS MUHAMMADIYAH YOGYAKARTA. UMY Research Repository, 113 Department of English Education. 1-44. http://repository.umy.ac.id/handle/123456789/7141

[9] Lestari, Ika \& Hardiyanti, Nuri. (2020). Vocabulary Learning Autonomy through Incorporation of English Songs: Indonesian EFL Students' Perspectives. 3L The Southeast Asian Journal of English Language Studies. 26. 94-104. http://doi.org/10.17576/3L-2020- 2602-07

[10] Malekian, S. (2016). The Relationship between English Songs and Learning Vocabulary. International Journal of African and Asian Studies, Vol. https://iiste.org/Journals/index.php/JAAS/article/view/29963

[11] Narayan, R. (2020). ENHANCING LEARNERS VOCABULARY SKILLS BY MEANS OF ENGLISH SONGS - AN EXPERIMENTAL STUDY. European Journal of Applied Linguistics Studies, 3(1). http://dx.doi.org/10.46827/ejals.v3i1.198

[12] Tien Cam Nguyen, Huan Buu Nguyen (2020). Teachers' Perceptions about Using Songs in Vocabulary Instruction to Young Language Learners. Universal Journal of Educational Research, 8(6), 2678 - 2685. http://dx.doi.org/10.13189/ujer.2020.080652 
18 Al-Saggaf, et.al.: The Perception of MSU BTESL Practicum Students Towards the Idea of Using English Songs with Written Lyrics in Teaching Vocabulary

[13] Safa, A.J. (2018). Effects of Using Songs on Adult EFL Learners' Vocabulary Learning. Journal of Applied $\begin{array}{llll}\text { Linguistics } \quad \text { Lnd } & \text { Research, } & \text { 5, }\end{array}$ http://www.jallr.com/index.php/JALLR/article/download/816/pdf816

[14] Sevik, Mustafa. (2011). Teacher views about using songs in teaching English to young learners. Educational Research and Reviews. 6(21). 1027-1035. https://academicjournals.org/journal/ERR/article-full-text-pdf/A8B97BB7582

[15] Shakerian, P., Rezaei, O., Murnani, Z. T., \& Moeinmanesh, H. (2016). Investigating the Role of Pop Songs on Vocabulary Recall, Attitude and Retention of Iranian EFL Learners: The Case of Gender. Advances in Language and Literary Studies, 7/2, 121- 128. http://dx.doi.org/10.7575/aiac.alls.v.7n.2p.121

[16] Tomczak, Ewa \& Lew, Robert. (2019). "The Song of Words": Teaching Multi-Word Units with Songs. 3L The Southeast Asian Journal of English Language Studies. 25. 16-33. http://dx.doi.org/10.17576/3L-20192504-02

[17] Zamin, Adzmi, Mohamad (2020). LEARNING VOCABULARY THROUGH SONGS: A STUDY ON THE ROLE OF MUSIC IN TEACHING VERBS. Humanities \& Social Sciences Reviews, 8, 550-557. https://doi.org/10.18510/hssr.2020.8167 